\title{
Determinants of Unethical Performance in Nigerian Construction Industry
}

\author{
L.O. OYEWOBI (Corresponding author), B. O GANIYU, A.A OKE, A. W OLA-AWO \& A. A SHITTU \\ Department of Quantity surveying, Federal University of Technology, Minna, Niger State, Nigeria \\ E-mail: Oyekunlehassankay@yahoo.com
}

Received: April 19, 2011

Accepted: June 7, 2011

doi:10.5539/jsd.v4n4p175

\begin{abstract}
Unethical performance is an impediment for economic development and good governance. It is more than true to say it is the bane of development in developing nations of the world under which Nigeria is categorized. The construction sector was highlighted for its practices in areas such as bribery, environmental destruction, capital flight, dangerous practices, poor quality, whistle blowing, etc. and it is also associated with unethical behaviour through the entire construction life cycle. This paper therefore, x-rayed the determinants of unethical performance in Nigerian construction industry with a view to identifying the causes in all the stages of building project. Well structured questionnaires were self administered to direct stakeholder involved in the execution of building projects considered for this research work. Literature review revealed that corruption is evident in the construction industry which causes a lot of setback to project such as abandonment of such project and if complete may be completed below standard. Data were presented and analyzed using non parametric statistic; tools used were Severity indices and Relative importance index rather than mean scores since the data were ordinal in nature. It was observed that the building construction industry is perceived to be more susceptible to ethical problems because of several features and that corruption has effect on all stages of construction right from Planning, Tender stage to Completion stage. It was recommended that viable legislation as a mechanism to deal with small levels of corruption by strengthening professional institutions that will punish erring members will prevent corruption to a certain degree; and enforcement and monitoring measures of anti corruption agencies is believed can enhance transparency, accountability and reduced unethical behavior, and this will create an enabling environment possible for the industry to thrive, operate, and improve on quality and quantity of infrastructure on a more sustainable basis and thereby foster good construction practice ethics.
\end{abstract}

Keywords: Construction industry, Corruption, Ethics and unethical performance

\section{Introduction}

The Nigerian construction industry is extremely susceptible to ethical erosion due to heterogeneous nature of the industry which makes it imperative for construction professionals to exhibit high level of professional ethics. One of the deters of meaningful development in the Nigerian Construction Industry is the menace of corruption and corrupt practices. Ameh and Odusami (2010a) submitted that the international community viewed corruption and other unethical issues as common occurrences at all stages of the Nigerian workforce considering the recent incessant rankings by the TI. TI (CPI, 2007) ranked Nigeria as the $2^{\text {nd }}, 3^{\text {tr }}, 6^{\text {th }}, 18^{\text {th }}$, and $37^{\text {th }}$ most corrupt nation in the world in 2003, 2004, 2005, 2006, and 2007, respectively. The ranking by CPI was based on acceptance of bribes and misuse of post by elite politicians and government officials to achieve their selfish goal. Kadembo (2008) posited that very few powerful politician rarely get prosecuted for crimes such as corruption, extortion and bribery or the use of public offices for personal benefit most especially in developing countries because the system of governance protects them. Kadembo (2008) further explained that there are double standard of laws being applied in most developing nations of the world - one for the political leaders and their cronies and the other for the poor and defenseless masses. The law for the poor masses appear to be fair because the emphasis is usually on the so-called rule of law- thoroughly investigated and prosecuted. While that of the political godfather or bigwigs appears to attract "lazy and tired" law enforcement agents. It was only the late Nigerian president Umar Yar'adua who appeared to strike the balance between the upper and the lower class. He restored sanity in the system which forestall normalcy in the execution and award of contract in construction industry, the law was straightened and there is no hide out for the so called "sacred cows". Many of them award contracts and at the same time execute the same contract with fictitious company's name.

On this premises, Frisch (1996) submitted that corruption is a common occurrence in all facets of life and has probably been in existence since the creation of mankind and as old as nature itself. CPI (2009) supported this that no country or region of the world is immune to the perils of corruption. Frisch (1996) further stressed that corrupt practices and corruption has been on the increase in the last two decades unabated and that the view could not have been nearer the nub of the matter in respect of the phenomenon of corruption and the new order of business, politics and society. Meghji (n.d) the phenomenon of corruption is part of the daily news but often goes unpunished to the detriment of the prosperity of the community at large. Globally, the construction industry of today has been built on the needs of the World's inhabitants to provide shelter, conquer distances (airport, 
road \& bridge construction), harness energy (construction of power stations for industrial development), create public spaces (tourist attraction \& relaxation centers), protect from natural disasters (construction of seawalls, dykes and groynes) and build historical monuments. The industry has moved away from only satisfying these basic needs of human existence because the process and environment in which those (direct stakeholders within the industry) involved in their production has become increasingly more sophisticated and challenging. Many projects are getting larger and more technical, both private and public clients requires high quality professional services of more specialized people and better control systems to offer satisfaction and give value for money.

Solomon (1994) argued that ethics are not place over business and that business itself is an ethics, defined by ethics, and made conceivable by ethics. Transparency International's Annual Corruption Report (2005) focused on the problems that the construction industry faces with its ethical image. Moodle, Smith and Preece (2008) reported the construction sector was highlighted for its practices in areas such as bribery, environmental destruction, capital flight, dangerous practices, poor quality, whistle blowing, etc. and that it also identified problems with unethical behaviour through the entire construction life cycle. Hence, construction is a global business that requires thoughtful consideration on its ethical performance. To achieve the aim of this paper, the research considered the following objectives; to identify the factors contributing to unethical performance at pre-tender stage and also to identify the factors contributing to unethical performance during project execution stage with a view to proffering appropriate recommendation to decimate the unethical behavior to a considerable level.

\section{Definition of Ethics}

Ethics is defined in the Oxford English Dictionary as the science of moral; moral principles or code. Whereas Morals are 'concerned with goodness or badness of human character or behaviour', or 'with the distinction between right and wrong', or 'concerned with accepted rules and standards of human behaviour' (Allen, 1990, p. 769). Robinson, Dixon, Preece and Moodley (2007) viewed ethics as a philosophical study of what is right or wrong in human conduct and what rules or principles should govern it. Mansfield (2008) considered ethics to be the explicit philosophical reflection on moral beliefs and practices. Prisms Business Media (2006) opined that ethics is a topic of extreme importance to most professionals in the industry but at the same time the least focused upon. The RICS (2000) was of the opinion that many organizations and writers have attempted to define ethics in their own context whether business, organizational, political, personal and professional. This assertion was corroborated by Wasserman (2000) that argued ethic comprises a study of thought, language, reasoning, processes and judgment that informs the choices people make in their daily lives that affect their own well-being and that of others.

Truly ethics is not all about definition because it does not, set down the code of ethics nor establish how the code of ethics might be prepared. However, Bowen et al.(2007) submitted that ethics is not just about recognizing an whether an objective is good but encompasses a careful thought in making viable choice or identifying if the choice is right or wrong. Within the construction industry context RICS (2000) posited ethics is a way of 'giving ones best to ensure that clients' interests are properly cared for, but in doing so the wider public interest is also recognized and respected! Mansfield (2008) submitted further that a token of a major profession is in its ability to accept the responsibility to act in the public interest which requires an overt commitment by its attachment to subdue personal advancement to this responsibility.

\section{Conceptual Underpinnings of Ethics and Ethical Performance.}

There are five basic assumptions which underpin the understanding of ethics and which are recognized by (RICS, 2000)

i. Professional Ethics is a process. Ethics are dynamic and cannot be learnt once. It is a way of reviewing behaviour against constantly changing standards. What may be ethical today, or in a particular society may be viewed differently by others or at another time.

ii. Human behavior is caused. There is always a motive for all unethical or ethical human behaviour. For example, for financial gain, power and compassion.

iii. Actions have consequences. There is cause and effect consequence. It can also be likened to Newton's Third Law of Physics that every force has an equal and opposite reaction.

iv. What is ethical depends on the individual's point of view. This is influenced by a variety of factors including published codes and statements

v. Good ethical business practice rests on mutual vulnerability. We are each susceptible to the actions of others, and the way we are treated depends on how we treat others. Respect is not a right, it must be earned. Therefore the need for professional ethics is based on the vulnerability of others. The client for example must be protected from exploitation in a situation in which they are unable to protect themselves because they lack the relevant knowledge to do so. 


\section{Effects of Unethical Behaviour and Conduct on the Industry}

Unethical and corrupt practices have a lot of adverse effect on the industry, to the development of the economy and human resources. Unethical or corrupt practices tends to distort construction process and thereby hamper economic fortune. Unethical performance hinders the free play of market forces, discourage economic aid from the foreign donors and it makes almost impossible to attract and international investors shun the corrupt environments to the detriment of the economies and communities of the respective countries (Kadembo, 2008)

Bribery and corruption are taken by many Nigerians as norm even in the face of anti-corruption crusades intended to support clean governance. Goldstock (1990) pointed out that a consequences of corruption is that it dramatically increases the cost of construction by undermining corruption for instance, corruption on residential projects eliminates both middle- and -low- income housing. Delays and cost overruns are the consequences of corrupt practices when a contractors deliberately overstate the time and cost requirements and falsify time sheets in order to achieve a higher price from the client to cover for the kickbacks and also concealment of the quality of work whereby defective materials could be used or cheaper materials and of inferior specification or materials omitted out rightly (Sohail and Cavil, 2009). Prisons Business Media Inc (2006) observes that unethical behaviour affects the cost of getting projects executed and that it adds between $0.005 \%$ and $5 \%$ to the cost. Rodriguez et al.( 2005) highlights the devastating impact of corruption in construction such as wasted tender expenses, tendering uncertainty, increased project costs, economic damage, blackmail, criminal prosecutions, fines, blacklisting, brand damage, and reputational risk among others. Szeffel (1998) stated corruption alters the character of institutional performance in the context of administrative efficiency, it undermines managerial efficiency and redirects resources from regional, country and global policies to individual interest. Shakantu and Chiocha (2009) reported that Corruption impacts negatively on the economy of a country as well as the as the capacity of the construction industry to address imperatives. Most projects that are abandoned by successive government in Nigeria either at Federal, State or Local Government levels are due to high level of corruption that take place between the government officials and contractors. Rose-Ackerman (2008) argued that corrupt kickbacks changing hands amongst parties to the contract are easy to hide in construction contracts, and the competitive nature of many bidding processes encourages firms to try to outwit them through payoffs. In addition, it was further stressed that once the contract is written, officials tend to extract payoffs from the contractor and unscrupulous contractors have an incentive to pay bribes that permit them to cut corners to increase profits. While Aaronson (2011) posited corruption affects not only the cost or time of projects but both the environment for business and policymaking. It was stressed further that effect of corruption has increased the level of awareness of corporate executives that corruption not only affects profits, but also increases business risk. Frynas (2005) and Aaronson ( 2009) submitted that corruption also affects the general public by influencing investment and deter public access to services such as good education, efficient healthcare deliveries, and good roads among other services. Corruption can undermine governance, erode public trust and truncate democracy and consequently complicate social responsibility.

\section{Checking Unethical Practices}

The introduction of Due process by the Nigerian Government is a major positive development to check unethical performance within the construction industry (Olugbekan, 2001). This is geared towards solving some of those problem associated with the award of contracts and ensuring that due process is followed in project execution in the country. Olugbekan (2001) further posited that "the gains that are derivable from the due process are as follows:

Good governance of public money and assets as a result of reduction in corrupt practices; Efficient and effective project management; Improvement in liquidity management of public funds; Enhancement of transparency, accountability and probity in government; Improvement in project cost management, expenditure and institutional control and Improvement in technical efficiency in management and utilization of resources.

Transparency International (2006) recommends the following instruments in fighting corruption within the pharmaceuticals industry and these could be as well be adapted for the construction industry,

$>$ Transparency

$>$ Codes of conduct

$>$ Civil society participation and oversight

$>$ Whistleblower protection

$>$ Reducing incentives for corruption

$>$ Conflict of interest rules

$>$ Integrity pacts and debarment

$>$ Rigorous prosecution

Transparency International (2006) further suggested the following as a way of curbing corruption in the building construction industry: Contracting opportunities are widely publicized; awards are made to those who meet the contractual requirement and make best offers; the rule are clear and fair; the process is transparent with predictable results and public officials are accountable. 
In order for the procurement process to achieve the above mentioned characteristics poised. Transparency international (2006), the competitive and bidding process should adhere to the following best practice principles: Give public notification of bidding opportunities; Document should be clear; set out the need; describe the bidding process and contract terms and conditions; give criteria for choosing the winner; secretly sealed bids submitted should be opened in the presence of the bidders at a specified time and place; impartial evaluation and comparison of bids by competent evaluators without influence of or interference by bidders or other parties; award of contract to bidder complying with all requirements and offering the best bid defined by the published selection criteria; requirement for sound independent audits of procurement processes and; requirement for third party monitoring of large procurements

\section{Research Methods}

The survey explores the opinions of a sample of Nigerian construction professionals with respect to corrupt practices such as collusion, fraud and bribery. Well structured questionnaire was used for the data collection. The survey involved a random selection of potential participants from the available listings of professional consultants and main contractors involved in the selected projects in the study area. The professions represented included architects, quantity surveyors, consulting engineers, resident engineers and contractors. One hundred questionnaire packages were sent out to the direct stakeholder on the identified projects. The direct stakeholders are the contractors, architects, quantity surveyors and engineers including the desk officer to the minister for works and housing. The projects were selected using a convenience random sampling. Eight five questionnaires were returned ( $85 \%$ response rate) this include contractors $(27 \%$ of respondents), architects and (21\% of respondents), quantity surveyors (30\% of respondents) and engineers (22\% of respondents). Virtually all the respondents $(90 \%)$ belong to one or more professional bodies with professional and are duly registered with their respective professional bodies. This finding supported Bowen et al. (2008) research which reported $98 \%$ and Vee and Skitmore (2003) that was centered on the Australian construction industry participants in which $90 \%$ of the respondents belong to professional bodies. Locally it affirms the report of Ameh and Odusami (2010b) that posited $90 \%$ of their respondents are either graduate member, corporate or fellow of their respective professional bodies. Respondents with 6 years and above working experience was $93 \%$ which is in line with Ameh and Odusami (2010b). This suggests that respondents have adequate experience, hence information provided by the respondents pertaining to unethical issues in the industry could be relied on.

\subsection{Analysis of Data}

From the submission of Olugbekan (2001) that corruption manifests itself in all stages of construction projects from initiation to completion stage, the research therefore considered factors that enthrone corrupt practices at planning-tender stage and project execution stage and the research adapted variables used by (Sichombo, Muya, Shakantu \&Kaliba, 2009). Data collected for the study were ordinal in nature in that the distances between the ratings assigned in the Likert scale are not known. The ratings in this scale indicate only a rank order of importance of the factors, rather than how much more important each rating is than the other. Using parametric statistics to analyse such data would not produce meaningful results, and therefore nonparametric tests were used in the analysis of the results because the survey utilized nominal and ordinal measurement scales. In the case of ordinal data that could be ranked, Severity index analysis was conducted on the sample data to rank the factors according to their relative importance. Severity indices rather than mean scores were used since the data were ordinal in nature. The severity indices was measured using the formula referenced by (Idrus and Newman, 2002).

$$
\text { S.I }=\left(\sum_{i=1}^{n=n} \frac{-w i f i) \times 100}{n}\right]
$$

Where:

S.I. is the severity index, $f i$ is the frequency of response, wi is the weight for each rating (= rating in scale/number of points in a scale), and $n$ is the total number of responses. $n$ is the valid number of respondents.

The following five levels of scoring was adopted 'extremely severe' (5 points), 'very severe' (4 points), 'severe' ( 3 points), 'Least severe' ( 2 points) and 'not severe' (1 point).

\subsection{Results and Discussion}

Unethical issues such as corruption is one of the major problems that plagues construction industry in developing countries like Nigeria. Although some previous researchers consider it to be an essential lubricant 'greasing' of the wheels but this go against the ethics of the industry. Corruption is evil and damaging because it erodes public morality and wastes scarce but limited national resources. Corruption is a menace that causes a lot of setback to so many meaningful project embarked by many successive government in Nigeria. From the result of the analysis it was evident that there exist relationship between corruption and the activities at different stages of project from planning to actual execution stage.

Major area where unethical professional behaviour is prevalent is the aspect of bidding for a contract project right from planning, prequalification, tendering and post tendering Stages. Sometimes the favoured contractor 
channel his effort at ensuring the success of his bid in either open or competitive tendering, buys out information from the professional who is the custodian of the confidential information especially the Client Quantity Surveyor to ensure that the favoured contractor presents the lowest tender figure. This unethical practice puts other qualified contractors at a disadvantage position especially when the award is strictly based on the lowest responsive tender as in the case of the "Due Process".

The propensity that bidders may collude together to share the market where the contractors tender a cover price so as to ensure that the preselected contractor wins the tender was ranked most at planning to tender stage with severity index of $84 \%$. collusive attitude of bidders have become a global issues (Ray, Hornibrook, Skitmore \& Zarkada-Fraser, 1999) asserted that there are five major issues in tendering that involve ethical implications. These includes, withdrawal, bid cutting, cover pricing, compensation of tendering costs, and collusion.

Zou (2006) supported this research findings that the construction company offer bribes (cash or in-kind) to client or the tender evaluation committee members in order to win the project; purposely lower the tendering prices or collusion in the tendering prices among construction companies also contributed to corrupt practices. Bowen et al (2008) also posited that most construction professionals believed that the industry displays a high incidence of unfair tendering practices, as well as over claiming and withholding payment for service delivery.

Distortion of pre-qualification by consultant where the contractor who bribed the consultant wins the project was ranked third (SI =78\%). listed synonyms for 'bribery', has been listed such as kickbacks, gratuities, baksheesh, sweeteners, pay-offs, speed and grease money, and regarded fraud as an economic crime that involves some kind of trickery, swindle or deceit and has a broader legal and popular term that covers more than bribery and embezzlement (Amundsen, 2000)

This was corroborated further by the argument of Rose-Ackerman (2008) that corrupt kickbacks changing hands amongst parties to the contract are easy to hide in construction contracts, and the competitive nature of many bidding processes encourages firms to try to outwit them through payoffs.

Fraudulent qualifications where the contractor makes false claim on his profile and asset declared which was ranked least $(\mathrm{SI}=73 \%)$ is a serious unethical issues in the industry and this go in line with the submission that it is necessary that the prequalifiers utilize and analyze all previous and present data regarding the potential contractors in order to prequalify them on an impartial and objective basis in order place the bidders on a level play ground(Ng \& Skitmore, 1995).

At the project execution stage it was evident that corruption really exists as a result of the analysis carried out which was in line with the finding reported by TI (2005) in Krishnan (2009) in a 2006 survey carried out in the U.K. by the Chartered Institute of Building which represents 45,000 project managers in the United Kingdom and overseas showed that a majority of all respondents believed that bribery and fraud were significant problems in the U.K. construction industry at the project execution stage. The research revealed that inflation of variation claim is more predominant at the execution stage of building ( $\mathrm{SI}=89 \%$ ) contracts where the quantities are jacked up and once payment is made the contractor and the consultants involved share the money

During the construction phase, it was also reported in a research carried out in Zambia that the most prevalent unethical practice in Zambian construction industry was the supply and use of inferior and cheap construction materials, with the contractor and consultant conniving to share the resulting financial benefits (Sichombo, Muya, Shakantu \&Kaliba, 2009). This was ranked third with SI of $78 \%$ by this research, meaning that corrupt practices to cut corners at the expense of quality work is a global issue that requires urgent attention..

Also Stansbury (2005a) asserted that Corruption, (the abuse of entrusted power for private gain), can occur during all phases of a construction project planning and design, tender, execution, and operation and maintenance, as illustrated in the review of literature.

Stansbury (2005a) further said that a representative of the project owner may bribe a government or local authority official in order to obtain planning permission for a project, or to obtain approval for a design that does not meet relevant building regulations. This result correlated with the research findings at the project execution stage, which was observed that government official could be bribed in order to obtain planning permission (SI = $45 \%$ ), also a contractor can bribe a supplier of materials to increase his prices (SI $=55 \%)$ while bribing an Arbitrator to give a favorable opinion when disputes arises were amongst factors that contribute to corruption at this stage $(\mathrm{SI}=51 \%)$.

At the post construction stage it was evident that corruption was established as a result of the analysis carried out which coincides with the assertion of Stansbury (2005a) that said Bribes can be paid to win operation and maintenance contracts and fraudulent practices can lead to inflated operation and maintenance costs in just the same way as during the tender and project execution phases. This result agreed with the research finding at the execution stage which revealed that a project owner representative can be bribed for approval of nonexistent work by the contractor(SI $=72 \%)$,. The range of ethical problems evident as in South African construction industry includes collusion, bribery, negligence, fraud, dishonesty and unfair practices among the participant in the industry (Bowen et al., 2008) and in furtherance it was opined that bribery in the form of payments and gifts, 
particularly to consultants, is prevalent, but unethical behaviour in the form of fraud does not appear to be as serious a problem.

The effect of corruption and corrupt practices as revealed by the literature ranged from project abandonment to litigation in case of unlawful determination by either party to the contract. The assertion of (Sohail \& Cavil , 2009) supported this by positing that delays and cost overruns are the consequences of corrupt practices when a contractors deliberately overstate the time and cost requirements and falsify time sheets in order to achieve a higher price from the client to cover for the kickbacks given to the consultants and also concealment of the quality of work whereby defective materials could be used or cheaper materials and of inferior specification or materials omitted out rightly. Transparency International's 2008 Bribe Payers Index capped it all by revealing that public works and construction were perceived to be the most corrupt industry sectors in the world

\section{Conclusion}

It was observed that ethical problems are evident in all the stages of building project rising from pre-tender stage to completion. The trend of unethical performance in Nigerian construction industry is a calamitous cancer eroding millions in lost resources that could have been utilized for the development of nation's infrastructure. The corruption crisis tends to have its roots at the echelons of power, whether in the public or private sector. Much of the catastrophes the industry is bewildered today was as a result of corruption which stalls development and hinder social and economic advancement. Thus, the pervasiveness of corrupt practices in the Nigerian construction industry if unabated, could retard the growth of the industry, and consequently reduce the contribution of the sector to the Gross Domestic Product (GDP).

Corruption on construction projects could only be eliminated if all participants in projects cooperated in the development and implementation of effective anticorruption actions, which addressed the perpetrators of the ethical problems. These participants include governments, financiers, project owners, contractors, consultants, and suppliers as well as the business and professional associations which represent these parties. Viable legislation as a mechanism to deal with small levels of corrupt by strengthening professional institutions that will punish erring members will prevent corruption to a certain degree; and enforcement and monitoring measures of anti corruption agencies is believed can enhance transparency, accountability and reduced unethical behavior, and this will create an enabling environment possible for the industry to thrive, operate, and improve on quality and quantity of infrastructure on a more sustainable basis and thereby foster good construction practice ethics.

Finally, Sensitization of major project participants to create awareness among their staff of the effect and consequences of corruption is imperative and this can be achieved by posting anticorruption rules at all project and site offices, providing anticorruption training for relevant staff to serve as check and balances, implementing a gifts and hospitality policy to engineer compliances.

\section{References}

Aaronson S. A. (2011). Limited partnership: Business, government, civil society, and the public in the extractive industries transparency initiative (eiti). Public Admin. Dev. 31, 50-63.

Agbu. O. (2003). Corruption and Human Trafficking: the Nigerian case. West Africa Review.

Albrecht, W.S., Wernz, G.W., Williams, T.L. (1995). Fraud, Bringing Light to the Dark Side of Business, Irwin, Homewood, Illinois.

Allen, R.E. (ed.) (1990). The Concise Oxford Dictionary of Current English, 8th edn, Clarendon Press, Oxford.

Ameh J.O and Odusami K. T. (2010a). Professionals' Ambivalence toward Ethicsin the Nigerian Construction Industry. Journal of Professional Issues in Engineering Education and Practice, 136(1), 9-16.

Ameh, J.O and Odusami, K.T. (2010b). 'Nigerian building professionals' ethical ideology and perceived ethical judgement', Australasian Journal of Construction Economics and Building, 10 (3) 1-13.

Amundsen, I. (2000). Analysis and definition of corruption and its common forms, Chr. Michelsen Institute Development Studies and Human Rights, Utstein Anti- Corruption Resource Centre, Norway, available at http:// www.u4.no/documents/showdoc.cfm?id523 (accessed 28 February 2007).

Bowen P., Akintoye A., Pearl R. and Edwards P. J. (2007). Ethical behaviour in the South African construction industry Construction Management and Economics, 25, 631-648.

Department for International Development (DFID). (2002). "Making connections: Infrastructure for poverty reduction." (www.dfid.gov.uk/ pubs/files/makingconnections.pdf) ( June 2, 2008).

DFID. (2007). Get what you pay for-UK leads the way in transparency in construction. Press release, 20 June 2007.

Dike, V. E. (2002). The State of education in Nigeria and the health of the nation in the Nigeria Economic Summit Group (NESG) periodical, June 2002. Also see Online Publication, Africa Economic Analysis, at www.afbis.com/analysis/education10204234737.htm. 
Frisch, D. (1996). Curbing international corruption; European Voice. 2(41), available onhttp://www.europeanvoice.com/archive/article.asp?id=2731, accessed 3.01.2007.

Frynas J. G. (2005). The false developmental promise of corporate social responsibility: evidence from multinational oil companies. International Affairs 81(3): 581-598.

Goldstock, R. (1990). Corruption and Racketeering in the New York City Construction Industry. New York University Press, New York.

Idrus, A.B. and Newman, J.B. (2002). Construction related factors influencing the choice of concrete floor systems. Journal Construction Management and Economics, 20,13-19.

International Center for Economic Growth. (1999). ICEG Information Brief 6, Causes and Effects of Corruption, Nairobi, 1999.

Kadembo E. (2008). Corruption and the Distortion of Technology Transfer and Marketing Processes: An Insight into Africa' Economic Malaise and the Decadence of Its Social Fabric. Journal of Sustainable Development1(1), 58-68.

Krishnan C. (2009). Combating Corruption in the Construction and Engineering Sector: The Role of Transparency International. Leadership and Management in Engineering. 112-114.

Maduagwe, M. O. (1996). Nigeria in search of political culture. The Political Class, Corruptionand Democratization. In Corruption and Democratization Nigeria, 13. 18-19 (Alex Gboyega ed.,1996).

Mansfield J.R. (2008). The ethics of conservation: some dilemmas in cultural built heritage projects in England. Engineering, Construction and Architectural Management, 15 (3), 270-281.

Meghji, M.R., http://www.asce.org/files/ppt/global/revisedrafikmeghi.ppt, accessed 6.01.07.

Moodley K.y, Smith N. and Preece C. N. (2008). Stakeholder matrix for ethical relationships in the construction industry. Construction Management and Economics, 26, 625-632.

Ng, S.T. and Skitmore, R.M. (1995). CPDSS - Decision Support System for Contractor Prequalification. Civil Engineering Systems, 2,133-159.

Nwabuzor, A. (2005). "Corruption and Development: New initiatives in Economic openness and Strengthened Rule of Law Ethics.” A publication of Springer, 59(1) 121-138.

Olugbekan .O. (2001). "Corruption in Engineering project s and how to check In NSE" paper delivered and submitted to Nigerian Society of Engineers. Ibadan-Nigeria pp 25.

PricewaterhouseCoopers'. (2003). Global economic crime survey, London.

Prisms Business Media. (2006). The Construction Industry Ethical Dilemma. http://ecmweb.com.mag/electric_construction_industrys_ehical/

Ray R., Hornibrook J., Skitmore M.and Zarkada-Fraser A. (1999). Ethics in tendering: a survey of Australian opinion and practice. Construction Management and Economics 17, 139-153.

Ribadu, M. N. (2003). "Economic Crime and Corruption in Nigeria: the causes Effect and efforts aimed at combating these vice in Nigeria." Paper presented at the Monaco World summit $5^{\text {th }}$ International summit On Transnational crime Monte-Carlo, 23-24 October2003.

RICS. (2000). Professional Ethics Guidance Note: Part 1 Introduction, RICS Professional Regulation and Consumer Protection Department, London.

Robb, D.J. (1996). Ethics in Project Management: Issues, Practice, and Motive, PM Network, Volume 10, (12), pp 13-16, 18 .

Robinson, S., Dixon, J.R., Preece, C.N. and Moodley, K. (2007). Engineering, Business and Professional Ethics, Butterworth-Heinemann, Oxford.

Rodriguez, D., Waite, G., and Wolfe, T., eds. (2005). "The Global Corruption Report 2005.”\{http://www.transparency.org/publications/gcr/download (2005\#download) (April 7, 2011).

Rose-Ackerman S. (2008). Briefing: Risks of corruption in government infrastructure Projects .Proceedings of the Institution of Civil Engineers Municipal Engineer 161September 2008 Issue ME3 Pages 149-150.

Sichombo B., Muya M. , Shakantu W., and Kaliba C. (2009). The need for technical auditing in the Zambian construction industry. International Journal of Project Management, 27, 821-832.

Sohail M and Cavill S. (2009). Accountability to Prevent Corruption in Construction Projects Journal of Construction Engineering and Management, 134( 9),729-738.

Stansbury, N. (2005a). "Exposing the foundations of corruption in construction." Global corruption report (2005) special focus: Corruption in construction and post conflict reconstruction, Pluto, London.

Stansbury, N. (2005b). Preventing corruption on construction projects-Risk assessment and proposed actions for project owners, Transparency International, Berlin. 
Stansbury, N. (2006). "Business not as usual" paper published by the chartered Institute of Builders, Journal of chartered Institute of Builders International $3^{\text {rd }}$ Quarter 2006.

Szeftel, M. (1998). "Misunderstanding African Politics: Corruption and the Governance agenda" Review of African Political Economy . 25(76). 221-240.

Transparency International Corruption Perception Index (CPI), 2001; 234-236

Transparency International. (2005). Global corruption report 2005, Pluto Press, London.

Transparency International. Corruption perceptions index regional highlights: Africa, $<$ http://www.transparency.org/policy_research/surveys_incices/cpi/2007/regional_highlights_factsheets/R egional_Facts_AF_Final_200907[1].pdf >; 2007.

Vee, C. and Skitmore, R.M. (2003). Professional ethics in the construction industry. Journal of Engineering, Construction and Architectural Management, 10(2), 117-27.

Wasserman, B. (2000). Ethics and Practice of Architecture, McGraw-Hill, New York.

Zarkada-Fraser, A. and Skitmore, R.M. (2000). Decisions with moral content: collusion. Construction Management and Economics, 18(1), 101-11.

Zou P. X.W. (2006). Strategies for Minimizing Corruption in the Construction Industry in China. Journal of Construction in Developing Countries, 11, (2), 15-29.

Table 1. Showing some identified factors contributing to unethical performance during pre-tender stage

\begin{tabular}{|c|c|c|c|}
\hline NO & FACTORS & RII & RANK \\
\hline 1 & $\begin{array}{l}\text { Distortion of pre-qualification by consultant where the contractor who } \\
\text { bribed the consultant wins the project }\end{array}$ & 78 & 3 \\
\hline 2 & $\begin{array}{l}\text { There may be, in relation to a project at confidential details such as the } \\
\text { project owner's non disclosure of financial status with the fear that } \\
\text { contractor may unlikely to start work if he was aware of the client } \\
\text { financial difficulties. }\end{array}$ & 82 & 2 \\
\hline 3 & $\begin{array}{l}\text { The bidders may collude together to share the market where the } \\
\text { contractors tender a cover price so as to ensure that the preselected } \\
\text { contractor wins the tender. }\end{array}$ & 84 & 1 \\
\hline 4 & $\begin{array}{l}\text { Fraudulent qualifications where the contractor makes false claim on his } \\
\text { profile and asset declared }\end{array}$ & 73 & 6 \\
\hline 5 & $\begin{array}{l}\text { The tender process may be corrupted by international pressure due to } \\
\text { interest in certain companies by either consultant or client which win the } \\
\text { contract }\end{array}$ & 78 & 3 \\
\hline 6 & $\begin{array}{l}\text { A representative of the project owner or government may directly or } \\
\text { indirectly own one of the bidders or where the favoured contractor adds } \\
\text { certain percentage to the contract sum for the official }\end{array}$ & 74 & 5 \\
\hline
\end{tabular}

Table 2. Showing some identified factors contributing to unethical performance during project execution stage

\begin{tabular}{|c|c|c|c|}
\hline NO & FACTORS & SI & RANK \\
\hline 1 & $\begin{array}{l}\text { The project owner may bribe a government official in order to obtain } \\
\text { planning permission for a project. }\end{array}$ & 45 & 7 \\
\hline 2 & $\begin{array}{l}\text { A contractor may pay a bribe to supplier of material to increases his } \\
\text { prices or supply cheap materials }\end{array}$ & 55 & 5 \\
\hline 3 & $\begin{array}{l}\text { If parties are in dispute in relation to the construction of the project, } \\
\text { one party may bribe an arbitrator to give a favourable opinion }\end{array}$ & 51 & 6 \\
\hline 4 & $\begin{array}{l}\text { Delay payment where project owner connive with architect to delay } \\
\text { issuance of payment certificate. }\end{array}$ & 86 & 2 \\
\hline 5 & $\begin{array}{l}\text { Fraudulent practice as a result of supply of inferior or cheap materials } \\
\text { where the consultant certifies but the contractor is paid in full for } \\
\text { quality materials. }\end{array}$ & 82 & 3 \\
\hline 6 & $\begin{array}{l}\text { Inflation of variation claim where the quantities are jacked up and once } \\
\text { payment is made they share the money. }\end{array}$ & 89 & 1 \\
\hline 7 & $\begin{array}{l}\text { A contractor may pay a bribe to the project owner's representative in } \\
\text { return for approval of defective or non-existent work. }\end{array}$ & 72 & 4 \\
\hline
\end{tabular}

